\title{
Identification of Hydrolytic Activities Expressed by Aspergillus flavus Grown on Cotton Carpel Tissue
}

3

4

5

6

7
U. S. Dept. of Agriculture, Agricultural Research Service, Southern Regional Research Center, 1100 Robert E. Lee Blvd., New Orleans, LA 70124, USA

* Corresponding Author, Tel.: +1 504286 4358; fax: 1504286 4419. Email address: Jay.Mellon@ars.usda.gov (J. E. Mellon). 


\section{Abstract}

23 To identify proteins important for invasion into host plant tissue, Aspergillus flavus was cultured

24 on medium containing cotton carpel tissue as the sole carbon source. We identified several

25 hydrolases suggesting they are important as A. flavus virulence factors for plant colonization.

26 Specifically, Aspergillus flavus AF13 secreted at least two endoxylanase activities and a

27 pectolytic activity when grown on the cotton carpel tissue medium. A concentrated sample

28 derived from the A. flavus growth medium (6-day) was subjected to gel filtration

29 chromatography on a BioGel P-30 column. A major endoxylanase activity was separated from

30 the other fungal-secreted proteins. Additional fungal secreted proteins were partially resolved by

31 gel filtration chromatography on a BioGel P-60 column. Multiple proteins with molecular

32 weights in the 20 to $70 \mathrm{kD}$ range were present in the harvested fungal growth medium. Analysis

33 of these fungal-secreted proteins by liquid chromatography/tandem mass spectrometry identified

34 both endo- and exo-glucanase proteins, $\alpha$-L-arabinofuranosidase, glucoamylase, $\alpha$-amylase A,

35 pectate lyase A, xylanase F1, acetylxylan esterase, glutaminase A, as well as conserved

36 hypothetical proteins of unknown function. These proteins likely assist A. flavus in the

37 maceration of plant cell walls, allowing for pathogenic entry and accession of host nutrient

38 resources. Pectolytic and xylanolytic hydrolases, as well as glucanases, appear to be important

39 A. flavus virulence factors.

40 Keywords: Aspergillus flavus, Xylanolytic hydrolases, Pectolytic hydrolases, Virulence factors,

41 Carpel tissue

42 


\section{Introduction}

Aspergillus flavus is a ubiquitous saprophytic fungus commonly found in tropical and subtropical climes [1]. This fungus is also an opportunistic pathogen of a number of oilseed crops, including peanuts, cotton, corn and tree nuts, and has agronomic significance due to its production of the potent carcinogenic mycotoxin aflatoxin $\left(\mathrm{B}_{1}\right)$ [2]. A. flavus is capable of producing a large array of hydrolytic enzymes, both for nutrient capture and penetration of host plant tissues [3]. Since plant reserve materials (free sugars, lipids, polysaccharides, proteins) that are potential fungal substrates are generally encapsulated within highly thickened protective wall tissues, production of hydrolases capable of aiding wall penetration is an important function for the fungus.

Pectin is a plant-produced methylated polymer of galacturonic acid [4]. The complex structural details of this class of polysaccharides have been recently reviewed [5]. Pectins are involved in formation of a matrix that, along with xylans, xyloglucans and cellulose, forms the bulk of the primary wall. In addition to this structural role in the wall proper, pectins (e.g. highly de-esterified homogalacturonans) are involved in cell adhesion [6], and connect epidermal cells to the surface cuticle (wax). Endopolygalacturonases or pectinases are a class of enzymes that hydrolyze long chain pectins at internal locations. Many plant pathogens secrete pectolytic enzymes to help macerate host wall tissues to assist in pathogen entry past host defenses [7]. The ability of A. flavus isolates to migrate between sections (locules) of developing cotton bolls (fruits) is highly correlated with the production of a specific endopolygalacturonase [8]. This specific pectinase (P2c) contributes to aggressiveness in A. flavus isolates on plants. Aspergillus

64 flavus $\mathrm{P} 2 \mathrm{c}$ pectinase is encoded by the pecA gene [9]. Evidence for the importance of P2c in A. 5 flavus invasiveness of cotton bolls is supported by increased virulence following the 
66 transformation of A. flavus strains lacking P2c with pecA [10]. These transformants acquire the

67 ability to cause increased intercarpellary membrane damage and invade adjacent locules. In

68 addition, removal of pecA activity through targeted disruption significantly reduces boll

69 invasiveness [10]. Thus, it appears that pectinase P2c is a contributing virulence factor of $A$.

70 flavus that is critical for maceration of plant tissues.

71 Xyloglucans and xylans comprise the complex hemicellulose fraction of plant cell walls.

72 They function within the cell wall to help give proper orientation to the cellulose microfibrils

73 (primary wall) and allow for wall expansion during wall growth [11]. Xylans are often

74 associated with highly thickened structures such as xylem cell walls and seed coats.

75 Endoxylanase activities hydrolyze the xylan backbone of these plant polysaccharides in a

76 random fashion at non-modified internal residues, yielding the production of xylo-oligomers.

77 This hydrolytic activity provides a major contribution towards plant cell wall maceration. Plant

78 xylans may also contain a variety of different residues attached to the xylan backbone. These

79 possibly include glucuronic acid, arabinose, galactose, ferulic acid and acetyl residues.

80 Production of additional specific hydrolases may be required to remove accessory substituents

81 before endoxylanases can gain access to the xylan backbone [12].

82 Cotton carpellary tissue is a tough, fibrous tissue that provides a physical barrier to potential

83 plant pathogens. This tissue divides the cotton fruit (boll) into sections (locules) and inhibits the

84 spread of microorganisms between different locules. Since carpel tissue provides an important

85 defense function for the host plant, an investigation was initiated to determine the identity of

86 secreted proteins and the composition of secreted hydrolytic activities when $A$. flavus is grown in

87 close association with cotton carpel tissue. Our findings help to further delineate fungal

88 virulence factors needed for breaching host defense barriers. 
98 size of $0.5 \mathrm{~mm}^{2}$.

\section{Materials and methods}

\subsection{Biological materials}

A. flavus AF13 was isolated from soil collected in southern Arizona and maintained on a 5\% V-8 vegetable juice (Campbell Soup Co., Camden, NJ, USA) agar at $30{ }^{\circ} \mathrm{C}$ [13]. Fungal conidial suspensions were constructed with sterile, deionized water and contained 1 to $2 \times 10^{6}$ conidia per mL. Remazol Brilliant Blue R and Ruthenium Red stain were obtained from Sigma Chemical Co. (St. Louis, MO, USA). Cotton (Gossypium hirsutum) carpel tissue was dissected by hand from bolls (35-45 d post-anthesis; variety MD52ne [14]) in a sterile environment; tissue was dried at $55^{\circ} \mathrm{C}$ for $24 \mathrm{~h}$. Dried carpel tissue was ground in a Wiley mill to an average particle

\subsection{Fungal liquid cultures}

A chemically defined culture medium [15], containing sucrose (2 g/L) and dried carpel tissue $(0.5 \mathrm{~g} /$ flask $)$ as a carbon source and sodium nitrate $(3 \mathrm{~g} / \mathrm{L})$ as a nitrogen source [16], was used as a fungal growth medium. The medium was adjusted to $\mathrm{pH} 5.5$ before heat sterilization. Incubations were conducted in $70 \mathrm{~mL}$ of medium in $250-\mathrm{mL}$ flasks. Each incubation flask was seeded with $200 \mu \mathrm{L}$ of a conidial suspension. Fungal fermentations were carried out in a shaking incubator $(150 \mathrm{rpm})$ in the dark at $30^{\circ} \mathrm{C}$ for 6 days. Fungal medium used as a source of secreted fungal proteins was filter-sterilized $(0.22 \mu \mathrm{m}$ filter $)$ before use.

\subsection{Gel filtration chromatography of fungal proteins}

BioGel P-30 (BioRad Labs, Richmond, CA, USA) gel filtration medium was equilibrated with 0.05 M 2-(N-Morpholino)ethanesulfonic acid (MES), pH 6.2, packed to form a 1.5 by 93cm column (bed vol. = $164 \mathrm{~mL}$; void vol. $=45 \mathrm{~mL}$ [est.]), and thoroughly washed with MES buffer. A. flavus AF13 sterile culture filtrate, $200 \mathrm{~mL}$, was concentrated 100-fold by means of 
112 Centriprep-3/Centricon-3 filter units (Millipore Corp., Beverly, MA, USA; mol. wt. cutoff, 3

$113 \mathrm{kD})$. The concentrated AF13 protein preparation was applied to the column and eluted with

114 MES buffer. After $40 \mathrm{~mL}$ of column eluant had passed through, forty 2-mL fractions were

115 collected. Column eluant (continuous flow) was monitored for $\mathrm{A}_{280 \mathrm{~nm}}$ and conductivity. Column

116 fractions were assayed for protein concentration $\left(\mathrm{A}_{280 \mathrm{~nm}}\right)$ and xylanase activity (radial diffusion

117 assay).

118 Using similar procedures to those used for the P-30 column, a BioGel P-60 (BioRad Labs)

1191.5 by $94-\mathrm{cm}$ column (bed vol. $=166 \mathrm{~mL}$; void vol. $=47 \mathrm{~mL}$ ) was packed and thoroughly

120 washed with MES buffer. Fractions from the P-30 column (fractions \#1-15) containing proteins

121 other than the lower molecular weight xylanase were pooled and concentrated 15 -fold using

122 Centriprep-3/Centricon-3 filter units. This concentrated AF13 protein sample was applied to the

123 column and eluted with MES buffer. After $40 \mathrm{~mL}$ of column eluant had passed through, twenty-

124 five 2-mL fractions were collected. Column eluant was monitored for $\mathrm{A}_{280 \mathrm{~mm}}$ and conductivity.

125 Column fractions were assayed for protein concentration $\left(\mathrm{A}_{280 \mathrm{~nm}}\right)$, xylanase activity (radial

126 diffusion assay), and pectinolytic activity (see below).

127 2.4. Xylanase activity assay

128 Oat spelt xylan was conjugated with Remazol Brilliant Blue R (RBB) according to a

129 previously published procedure [17]. Activity was observed by means of a semi-quantitative

130 radial diffusion assay in a medium containing $0.05 \%$ (w/w) RBB-xylan and $2 \%$ agar (9-cm gel

131 plates). Digestion of RBB-xylan produced a circular expanding clear zone surrounded by a thin

132 (1 mm) layer displaying a higher intensity of blue color (RBB-xylan fragments). Wells, $5 \mathrm{~mm}$ in

133 diameter, were cut into the gel medium and filled with test solution $(40-50 \mu \mathrm{L})$. Column

134 fractions were diluted 1:10 or 1:1 with MES buffer before application to assay plates. Assay 
135 plates were incubated at $37^{\circ} \mathrm{C}$ (dark) for 5 to $6 \mathrm{~h}$. The diameter of each digestion zone was

136 measured and activity level is reported as area of the RBB-xylan digestion zone (total area less

137 well area).

$138 \quad$ 2.5. Pectinolytic activity assay

139 Activity was observed by means of a radial diffusion assay in a medium containing $0.5 \%$

140 pectin, $1.0 \%$ agarose, $50 \mathrm{mM}$ potassium acetate ( $\mathrm{pH}$ 5.2) and $10 \mathrm{mM}$ EDTA (9-cm gel plates).

141 Wells, $5 \mathrm{~mm}$ in diameter, were cut into the gel medium and filled with test solution $(50 \mu \mathrm{L})$.

142 Column fractions (5 $\mu \mathrm{L})$ were diluted 1:10 with MES buffer before application to assay plates.

143 Assay plates were incubated at $37{ }^{\circ} \mathrm{C}$ (dark) for $18 \mathrm{~h}$ and stained with aqueous $0.1 \%$ ruthenium

144 red solution for $30 \mathrm{~min}$; they were destained with deionized water. Digested pectin zones

145 appeared as white circular areas surrounded by a red background. Diameters of digestion zones

146 were measured; activity levels are reported as areas of the pectin digestion zones (total area less

147 well area) [18].

148 2.6. Electrophoretic analysis

149 Denatured SDS-PAGE was performed generally according to the method of Laemmli [19].

150 Gels $(12 \% \mathrm{~T}, 3 \% \mathrm{C} ; 0.08 \times 8 \times 7 \mathrm{~cm})$ were run at 150 volts (constant) at $25^{\circ} \mathrm{C}$ in both the

151 stacking gel and the resolution gel. Aliquots from column fractions (MES buffer) were diluted

$152 \quad 1: 1$ with gel sample buffer (2x concentration) containing $50 \mathrm{mM}$ dithiolthreitol (DTT) and heated

153 at $100{ }^{\circ} \mathrm{C}$ for $2 \mathrm{~min}$. Protein molecular mass standards were obtained from Sigma-Aldrich (St.

154 Louis, MO, USA). Proteins were detected with GelCode Blue stain (Thermo Scientific,

155 Rockford, IL, USA) using the microwave procedure.

156 2.7. Peptide library preparation; LC-MS/MS mass spectrometry 
Protein bands were excised from gels manually with a razor blade. Due to low protein

158 concentrations, gel bands for a given molecular weight were obtained from one to two lanes and

159 pooled for analysis. Gel slices were diced into small cubes, rinsed in deionized water and soaked

160 in $100 \mathrm{mM}$ ammonium bicarbonate in $50 \%(\mathrm{v} / \mathrm{v})$ acetonitrile. The ammonium bicarbonate/

161 acetonitrile was removed, and the gel slices were dried in vacuo. Dried gel samples were re-

162 swelled with $100 \mathrm{mM}$ ammonium bicarbonate containing $5 \mathrm{mM}$ DTT, followed by alkylation

163 with $15 \mathrm{mM}$ iodoacetamide (Sigma-Aldrich). Reducing/alkylation solutions were removed; gel

164 samples were again dried in vacuo. Gel samples were incubated in $25 \mathrm{mM}$ ammonium

165 bicarbonate with $0.2 \mu \mathrm{g}$ of sequence-grade modified trypsin (Promega, Madison, WI, USA) at 37

$166{ }^{\circ} \mathrm{C}$ overnight. Supernatants from the digested gel samples were collected and dried in vacuo.

167 Dried peptide library samples were re-suspended in 5\% formic acid and analyzed by means of

168 liquid chromatography-tandem mass spectrometry (LC-MS/MS) in an Agilent 1200 LC system

169 with an Agilent Chip Cube interface to an Agilent 6520 Q-TOF tandem mass spectrometer

170 (Agilent Technologies, Santa Clara, CA, USA). Data files were processed with Spectrum Mill

171 software (Agilent Technologies) for peptide sequencing/protein identification using an A. flavus

172 (NRRL 3357) specific library down-loaded from the NCBI database.

\section{3. Results}

174 Gel filtration chromatography of the AF13 secreted protein sample with BioGel P-30 afforded

175 complete separation of a very small $\mathrm{A}_{280 \mathrm{~nm}}$ peak (labeled with arrow) from the other fungal-

176 secreted proteins. This $\mathrm{A}_{280 \mathrm{~nm}}$ peak (fractions 25-35) coincided with a major peak of

177 endoxylanase activity (Fig. 1). This endoxylanase activity previously has been characterized

$178[20,21]$ and is associated with a thermostable $14 \mathrm{kD}$ protein. An additional xylanase activity

179 peak corresponded to earlier eluting $\mathrm{A}_{280 \mathrm{~nm}}$ material (Fig. 1; labeled with asterisk). 
It was known from previous work [22] that carpel tissue contained high concentrations of xylans and arabinoxylans in the secondary wall structures, as well as pectins in the primary wall structure. Thus, column fractions were assayed for the presence of xylanase and pectolytic activities. Gel filtration chromatography of the pooled, re-concentrated AF13 sample with

184 BioGel P-60 resulted in the elution of three poorly separated $\mathrm{A}_{280 \mathrm{~nm}}$-absorbing peaks. The 185 additional

190

191

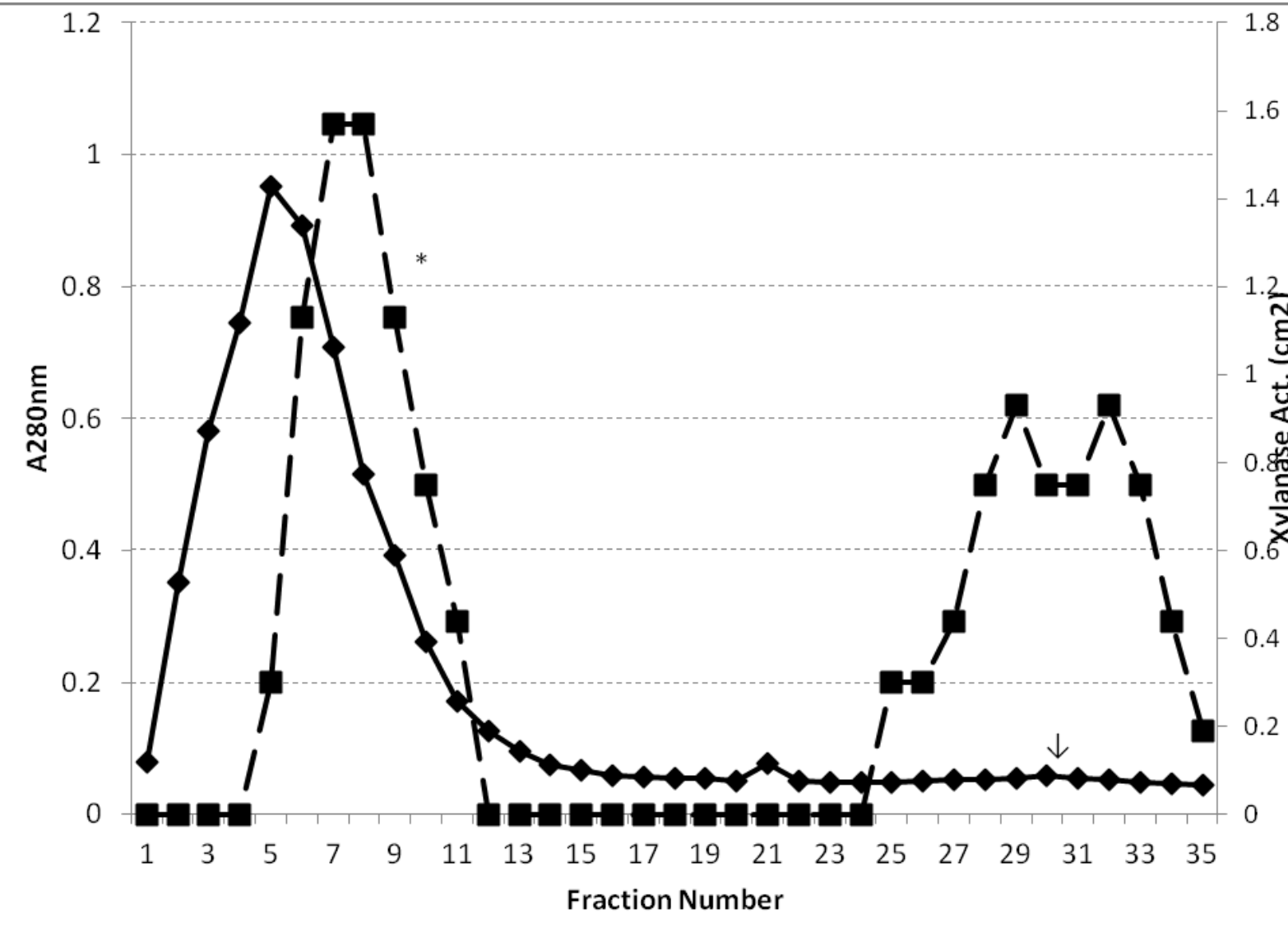

Fig. 1. Elution profile of A. flavus AF13 carpel medium protein preparation on a BioGel P-30 gel filtration column. Two-mL fractions were monitored for protein concentration $\left(\mathrm{A}_{280 \mathrm{~mm}}\right.$; solid line) and xylanase activity (radial diffusion assay; dashed line).

endoxylanase activity peak was associated with the trailing edge of the major $A_{280 n m}$ peak

(fractions \#9-18, Fig. 2). An activity peak of pectolytic activity was associated with trailing 
193 side of the major $\mathrm{A}_{280 \mathrm{~nm}}$ peak (Fig. 3), just prior to elution of the additional endoxylanase peak

194 (fractions \#9-13).

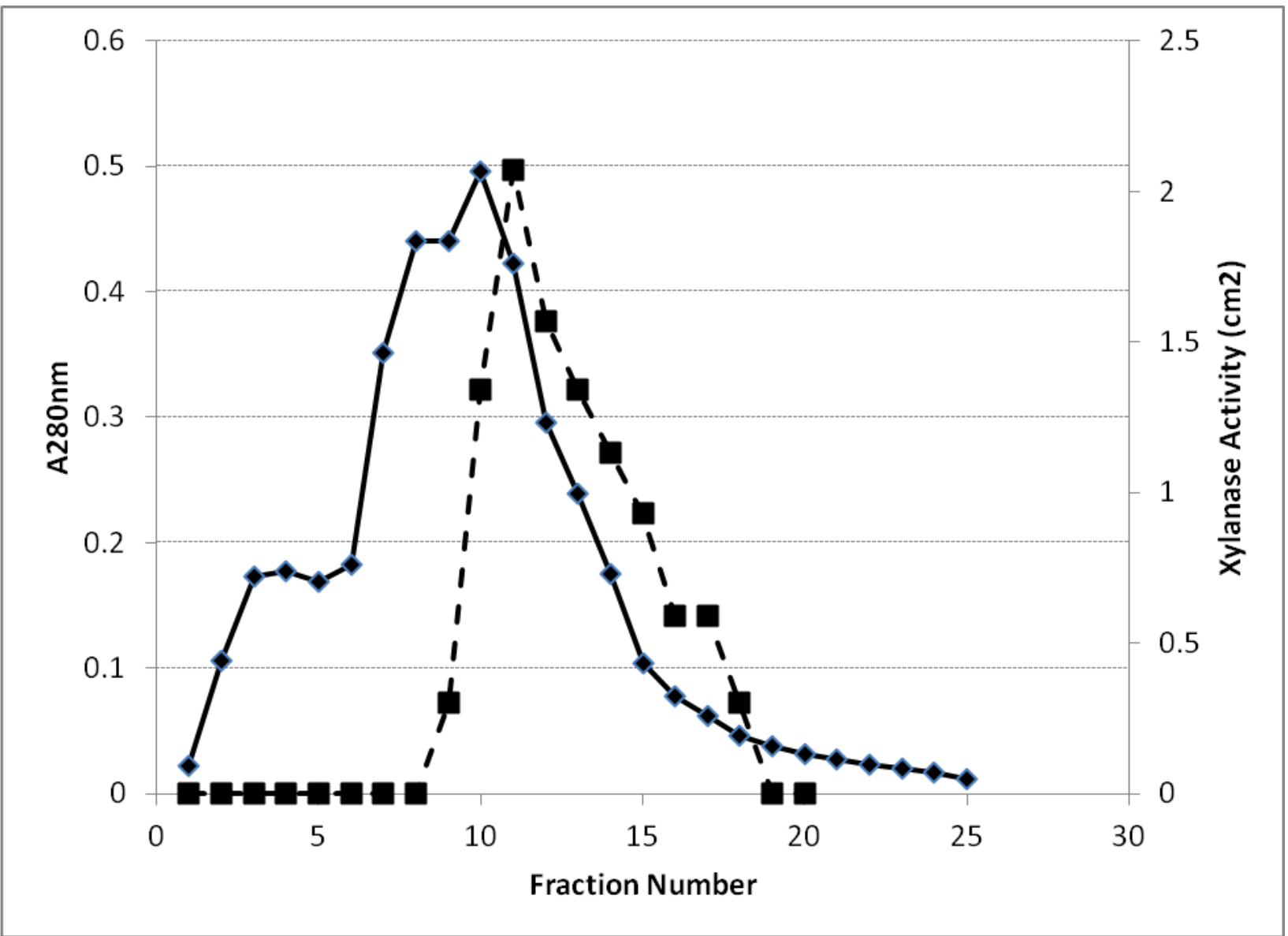

195

196

197

198

199

200

201

202

203

204

205

206
Fig. 2. Elution profile of A. flavus AF13 carpel medium proteins (less $14 \mathrm{kD}$ xylanase) on a BioGel P-60 gel filtration column. Two-mL fractions were monitored for protein concentration $\left(\mathrm{A}_{280 \mathrm{~nm}}\right.$; solid line) and xylanase activity (dashed line).

Analysis of the P-60 column fractions by SDS-PAGE revealed the presence of multiple fungal proteins with a large range of estimated molecular weights. Initially-eluting material contained prominent protein bands in the $70 \mathrm{kD}$ and $60 \mathrm{kD}$ regions (fractions 5, 7; Fig. 4A).

Column fractions corresponding to the leading side of the major $\mathrm{A}_{280 \mathrm{~nm}}$-absorbing peak displayed high concentrations of proteins in the 58 to $60 \mathrm{kD}$ range (fraction 9), whereas fractions corresponding to the trailing edge of this peak contained proteins displaying a wider range of estimated molecular weights (25-60 kD, fractions 11-12) (Figs. 4B and 4C). Fractions eluting in 
207 the tailing area of this $\mathrm{A}_{280 \mathrm{~nm}}$-absorbing peak contained proteins in the 25 to $27 \mathrm{kD}$ range

208 (fraction 14; Fig. 4C).

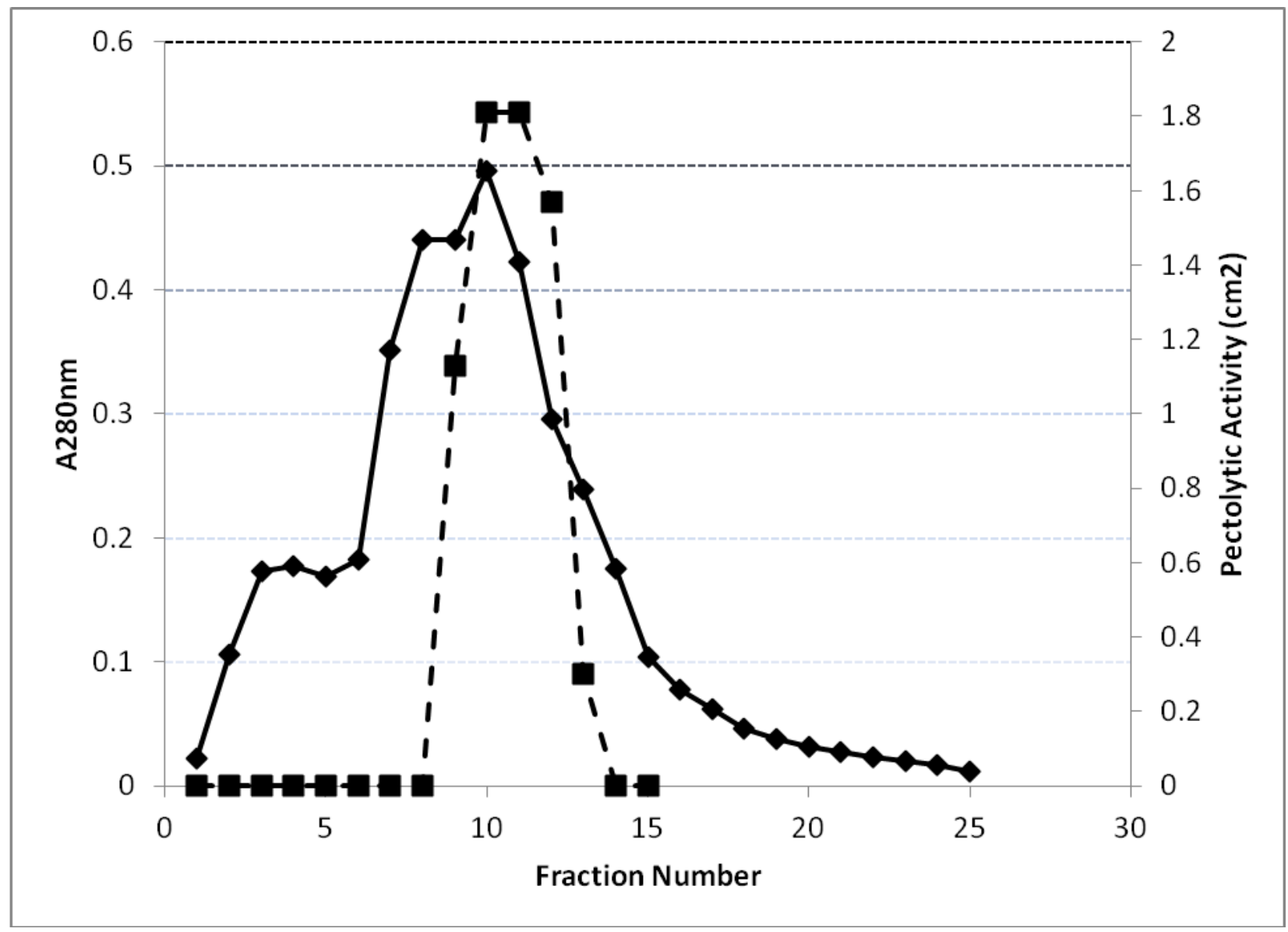

210 Fig. 3. Elution profile of A. flavus AF13 carpel medium proteins (less $14 \mathrm{kD}$ xylanase) on a 211 BioGel P-60 gel filtration column. Two-mL fractions were monitored for protein concentration

212 ( $\mathrm{A}_{280 \mathrm{~nm}}$; solid line) and pectinolytic activity (radial diffusion plate assay; dashed line).

214 In order to better characterize the proteins and attempt to identify these secreted A. flavus

215 proteins, gel bands were isolated and subjected to proteomics analysis. Fungal protein bands for

216 a given molecular weight region were excised, pooled and treated with trypsin to generate

217 peptide libraries for each protein; the peptide libraries were analyzed by liquid

218 chromatography/tandem mass spectrometry. Results from the 70-kD 'band' revealed several

219 peptide matches to multiple fungal proteins, including a hypothetical protein similar to 
extracellular endoglucanase (AFL2G_01726), a catalase B precursor (AFL2G_08106), a

221 hypothetical protein similar to glutaminase A (AFL2G_11013), a hypothetical protein similar to

$222 \beta$-fructofuranosidase precursor (AFL2G_10707), a hypothetical protein similar to $\alpha$-L-

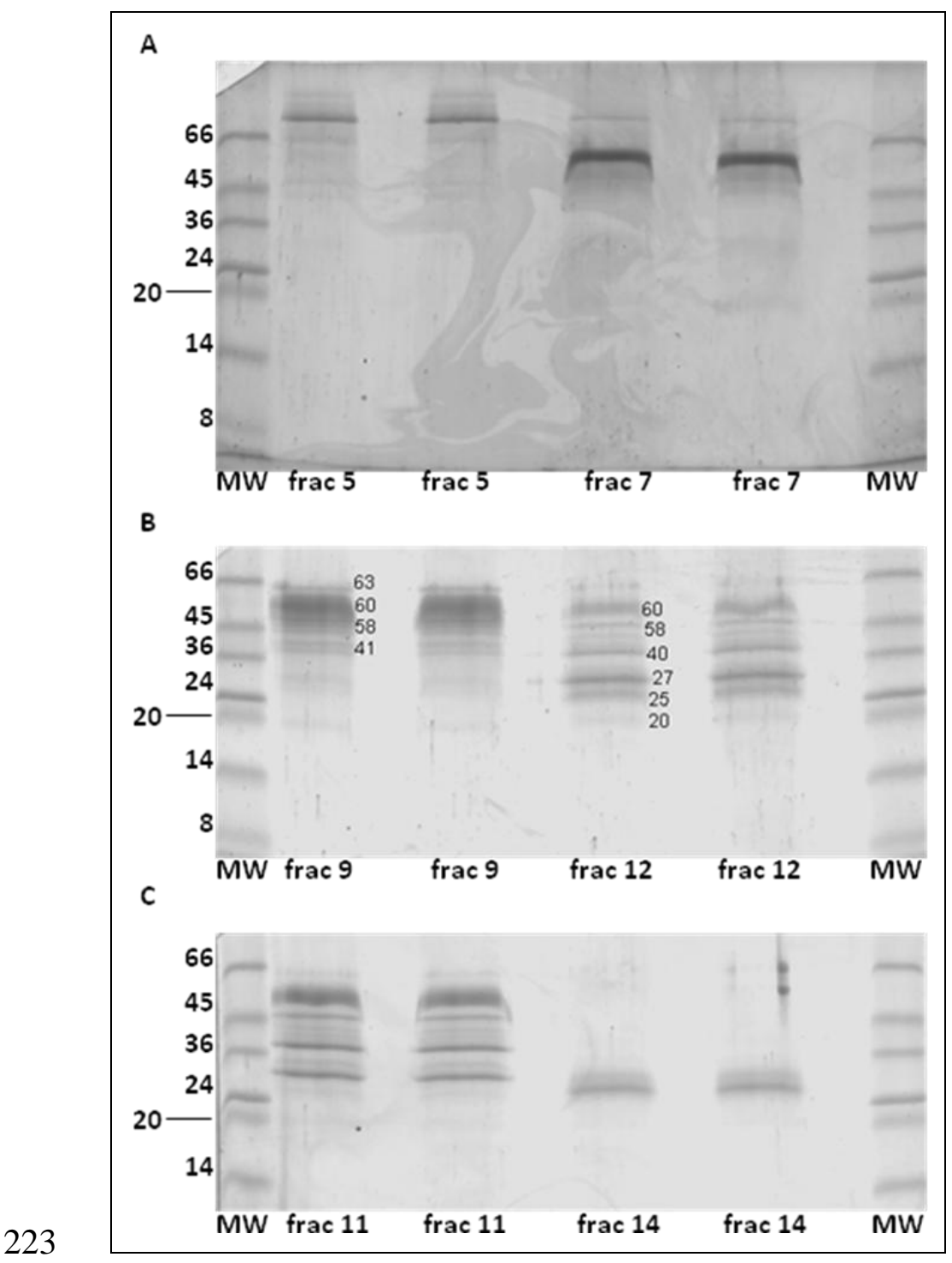

224 Fig. 4ABC. SDS-PAGE analysis of A. flavus AF13 carpel medium proteins. Samples were derived from P-60 column fractions. Protein samples are identified by the fraction number below each lane; protein molecular weight standards are shown in the edge lanes of each gel.

228 arabinofuranosidase A (AFL2G_03217), as well as conserved hypothetical proteins (Table 1).

The following proteins were identified from peptide matches to the $63-\mathrm{kD}$ band region: an 
233 matching the following identities: two different exoglucanase 1 precursor proteins

234 (AFL2G_07571; AFL2G_03805), an exoglucanase 2 precursor protein (AFL2G_07776), an $\alpha$ 235 amylase A type 3 precursor (AFL2G_01841) and a glucoamylase precursor (AFL2G_11885)

236 (Tables 1 and 2).

237 Table 1. Summary of LC/MS-MS protein identification

\begin{tabular}{|c|c|c|c|c|}
\hline protein band/kDa & protein & ORF & $\begin{array}{l}\text { peptide } \\
\text { matches }\end{array}$ & $\begin{array}{c}\text { protein } \\
\text { coverage (\%) }\end{array}$ \\
\hline 70 & conserved hypothetical & AFL2G_11529 & 9 & 20 \\
\hline 70 & $\begin{array}{c}\text { hypothetical similar to } \\
\text { extracellular endoglucanase }\end{array}$ & AFL2G_01726 & 9 & 25 \\
\hline 70 & catalase B precursor & AFL2G_08106 & 8 & 15 \\
\hline 70 & similar to glutaminase $\mathrm{A}$ & AFL2G_11013 & 8 & 21 \\
\hline 70 & $\begin{array}{c}\text { similar to beta- } \\
\text { fructofuranosidase }\end{array}$ & AFL2G_10707 & 8 & 17 \\
\hline 70 & conserved hypothetical & AFL2G_01386 & 7 & 12 \\
\hline 70 & $\begin{array}{c}\text { hypothetical similar to alpha- } \\
\text { L-arabinoduranosidase A }\end{array}$ & AFL2G_03217 & 5 & 13 \\
\hline 70 & hypothetical protein & AFL2G_02099 & 4 & 3 \\
\hline 63 & exoglucanase 1 precursor & AFL2G_07571 & 4 & 19 \\
\hline 63 & glucoamylase precursor & AFL2G_11885 & 4 & 15 \\
\hline 60 & exoglucanase 1 precursor & AFL2G_07571 & 8 & 36 \\
\hline 60 & $\begin{array}{c}\text { alpha-amylase type-3 } \\
\text { precursor }\end{array}$ & AFL2G_01841 & 5 & 18 \\
\hline 60 & glucoamylase precursor & AFL2G_11885 & 4 & 11 \\
\hline 60 & exoglucanase 2 precursor & AFL2G_07776 & 4 & 26 \\
\hline 60 & exoglucanase 1 precursor & AFL2G_03805 & 3 & 19 \\
\hline 58 & exoglucanase 2 precursor & AFL2G_07776 & 3 & 21 \\
\hline 58 & exoglucanase 1 precursor & AFL2G_07571 & 3 & 13 \\
\hline 55 & exoglucanase 1 precursor & AFL2G_03805 & 11 & 43 \\
\hline 55 & glucoamylase 1 precursor & AFL2G_02658 & 8 & 28 \\
\hline 55 & $\begin{array}{c}\text { hypothetical similar to } \\
\text { rhamnogalacturonan lyase } A\end{array}$ & AFL2G_05136 & 6 & 19 \\
\hline 55 & $\begin{array}{l}\text { alpha-amylase type-3 } \\
\text { precursor }\end{array}$ & AFL2G_01841 & 3 & 7 \\
\hline 41 & exoglucanase 1 precursor & AFL2G_07571 & 3 & 13 \\
\hline 40 & pectin lyase $A$ precursor & AFL2G_11352 & 3 & 20 \\
\hline 27 & $\begin{array}{c}\text { hypothetical similar to } \\
\text { xylanase F1 }\end{array}$ & AFL2G_11983 & 7 & 35 \\
\hline
\end{tabular}


239 Proteins identified from peptides within the 58-kD gel band region included an exoglucanase 1

240 precursor (AFL2G_7571) and an exoglucanase 2 precursor (AFL2G_07776) (Tables 1 and 2).

241

242 Table 2. Matched library of observed LC-MS/MS peptides

\begin{tabular}{|c|c|c|c|c|c|c|}
\hline $\begin{array}{l}\text { protein } \\
\text { band } \\
\text { (kDa) }\end{array}$ & Peptide sequence & $\begin{array}{c}\mathrm{m} / \mathrm{z} \\
\text { measured } \\
(\mathrm{Da})\end{array}$ & $\begin{array}{c}\mathrm{MH}+ \\
\text { matched } \\
\text { (Da) }\end{array}$ & $\begin{array}{l}\mathrm{MH+} \\
\text { error } \\
\text { (ppm) }\end{array}$ & $\begin{array}{l}\text { Accession } \\
\text { number }\end{array}$ & protein name \\
\hline 70 & (R)ADDVLEVNPLADPEVVSYFR(A) & 750.0426 & 2248.113 & 0 & AFL2G_11529 & $\begin{array}{c}\text { conserved } \\
\text { hypothetical }\end{array}$ \\
\hline 70 & (R)ELVGYVPWTHDLPDDTEEFAQAWK(H) & 949.4467 & 2846.331 & -1.8 & AFL2G_11529 & $\begin{array}{l}\text { conserved } \\
\text { hypothetical }\end{array}$ \\
\hline 70 & (R)GGILDLEEDYDADTGSPIVGLTR(S) & 802.728 & 2406.167 & 1 & AFL2G_11529 & $\begin{array}{c}\text { conserved } \\
\text { hypothetical }\end{array}$ \\
\hline 70 & (R)IPLFESSASDIQDVYYYR(W) & 722.6841 & 2166.039 & -0.6 & AFL2G_11529 & $\begin{array}{l}\text { conserved } \\
\text { hypothetical }\end{array}$ \\
\hline 70 & (K)LLGQEDVANNYQQQADDIK(K) & 721.3489 & 2162.036 & -1.8 & AFL2G_11529 & $\begin{array}{l}\text { conserved } \\
\text { hypothetical }\end{array}$ \\
\hline 70 & (K)LLGQEDVANNYQQQADDIKK(T) & 573.2887 & 2290.131 & 0.9 & AFL2G_11529 & $\begin{array}{l}\text { conserved } \\
\text { hypothetical }\end{array}$ \\
\hline 70 & (K)SDYASFLYGPYR(N) & 719.8357 & 1438.664 & 0.3 & AFL2G_11529 & $\begin{array}{l}\text { conserved } \\
\text { hypothetical }\end{array}$ \\
\hline 70 & (R)TNEPSYEYYMR(Q) & 726.808 & 1452.61 & -0.9 & AFL2G_11529 & $\begin{array}{c}\text { conserved } \\
\text { hypothetical }\end{array}$ \\
\hline 70 & (R)YKVDNEYVTYWDFIR(G) & 670.9915 & 2010.96 & 0.2 & AFL2G_11529 & $\begin{array}{c}\text { conserved } \\
\text { hypothetical }\end{array}$ \\
\hline 70 & (K)FSSGASPVVQLVQWDTPTLSK(T) & 1124.0861 & 2247.166 & -0.3 & AFL2G_01726 & $\begin{array}{l}\text { hypothetical similar } \\
\text { to extracellular } \\
\text { endoglucanase }\end{array}$ \\
\hline 70 & (K)INKFNEIFLR(A) & 431.916 & 1293.731 & 1.6 & AFL2G_01727 & $\begin{array}{c}\text { hypothetical similar } \\
\text { to extracellular } \\
\text { endoglucanase } \\
\end{array}$ \\
\hline 70 & (R)LPVTWTHHFTSESPDWTVDPK(W) & 620.803 & 2480.188 & 0.8 & AFL2G_01728 & $\begin{array}{l}\text { hypothetical similar } \\
\text { to extracellular } \\
\text { endoglucanase }\end{array}$ \\
\hline 70 & (K)LWYQIGTK(L) & 504.7794 & 1008.551 & 0.2 & AFL2G_01729 & $\begin{array}{l}\text { hypothetical similar } \\
\text { to extracellular } \\
\text { endoglucanase }\end{array}$ \\
\hline 70 & (K)RVVNLVGGGMDSVK(T) & 477.6003 & 1430.778 & 5.5 & AFL2G_01730 & $\begin{array}{l}\text { hypothetical similar } \\
\text { to extracellular } \\
\text { endoglucanase }\end{array}$ \\
\hline 70 & (K)SSMVAFETINEPPCNTAEDGAK(I) & 790.0202 & 2368.043 & 1.2 & AFL2G_01731 & $\begin{array}{c}\text { hypothetical similar } \\
\text { to extracellular } \\
\text { endoglucanase }\end{array}$ \\
\hline 70 & (K)TSAAASSISGSDLSIPITWK(G) & 664.6803 & 1992.028 & -1 & AFL2G_01732 & $\begin{array}{l}\text { hypothetical similar } \\
\text { to extracellular } \\
\text { endoglucanase }\end{array}$ \\
\hline 70 & (R)VSDVIDMITSR(G) & 618.3195 & 1235.63 & 1.4 & AFL2G_01733 & $\begin{array}{l}\text { hypothetical similar } \\
\text { to extracellular } \\
\text { endoglucanase }\end{array}$ \\
\hline 70 & (R)VVNLVGGGMDSVK(T) & 637.8433 & 1274.677 & 1.6 & AFL2G_01734 & $\begin{array}{c}\text { hypothetical similar } \\
\text { to extracellular } \\
\text { endoglucanase }\end{array}$ \\
\hline 70 & (R)AVSPSFEDVWSQPR(L) & 802.8809 & 1604.77 & -9.9 & AFL2G_08106 & catalase B precursor \\
\hline 70 & (K)FGFDLFDPTK(I) & 593.7923 & 1186.578 & -0.5 & AFL2G_08106 & catalase B precursor \\
\hline 70 & (R)FGKPVGAVGSAATALK(N) & 491.9531 & 1473.842 & 1.6 & AFL2G_08106 & catalase B precursor \\
\hline
\end{tabular}




\begin{tabular}{|c|c|c|c|c|c|c|}
\hline 70 & (R)GPTLLEDFIFR(Q) & 654.3541 & 1307.699 & 1.2 & AFL2G_08106 & catalase B precursor \\
\hline 70 & (R)GVDFTEDPLLQGR(L) & 723.8588 & 1446.722 & -8.3 & AFL2G_08106 & catalase B precursor \\
\hline 70 & (R)HGGPNFEQLPINQPR(V) & 568.6257 & 1703.861 & 0.8 & AFL2G_08106 & catalase B precursor \\
\hline 70 & (K)IVPEEYVPITK(L) & 644.3631 & 1287.72 & -0.4 & AFL2G_08106 & catalase B precursor \\
\hline 70 & (K)SVTSGFVDGIK(D) & 555.2931 & 1109.584 & -4.3 & AFL2G_08106 & catalase B precursor \\
\hline 70 & (R)AISTNWPVFAFSR(D) & 748.3883 & 1495.769 & 0.1 & AFL2G_11013 & $\begin{array}{c}\text { similar to } \\
\text { glutaminase A }\end{array}$ \\
\hline 70 & (R)DMFHQALATWINETPTNR(A) & 715.6774 & 2145.018 & -0.3 & AFL2G_11013 & $\begin{array}{c}\text { similar to } \\
\text { glutaminase A }\end{array}$ \\
\hline 70 & (R)ELGLNLVPQSVYDMQNTFYPTVK(E) & 886.1161 & 2656.333 & 0.4 & AFL2G_11013 & $\begin{array}{c}\text { similar to } \\
\text { glutaminase A }\end{array}$ \\
\hline 70 & (K)FLSPITPDDLR(R) & 637.3424 & 1273.679 & -0.9 & AFL2G_11013 & $\begin{array}{c}\text { similar to } \\
\text { glutaminase A }\end{array}$ \\
\hline 70 & (R)ISKDSIDAAGQDYLTITSLTVR(Q) & 789.7527 & 2367.24 & 1.4 & AFL2G_11013 & $\begin{array}{c}\text { similar to } \\
\text { glutaminase } A\end{array}$ \\
\hline 70 & (R)NAIAQWDYGVTDDGVAYHK(V) & 708.3316 & 2122.983 & -1.2 & AFL2G_11013 & $\begin{array}{c}\text { similar to } \\
\text { glutaminase } A\end{array}$ \\
\hline 70 & (R)QVFAAVQLTGTPEDPYIFMK(E) & 1128.0736 & 2255.142 & -0.8 & AFL2G_11013 & $\begin{array}{c}\text { similar to } \\
\text { glutaminase } A\end{array}$ \\
\hline 70 & (K)SYFSTATAALEFFHHDYAAAAALSK(D) & 673.329 & 2690.289 & 2.1 & AFL2G_11013 & $\begin{array}{c}\text { similar to } \\
\text { glutaminase } A\end{array}$ \\
\hline 70 & (R)AWYENGITNCVGDNTR(T) & 623.941 & 1869.818 & -5.3 & AFL2G_01386 & $\begin{array}{l}\text { conserved } \\
\text { hypothetical }\end{array}$ \\
\hline 70 & (K)DNTCNAPIPVSFPVAPTDTK(G) & 715.3491 & 2144.033 & 0 & AFL2G_01386 & $\begin{array}{l}\text { conserved } \\
\text { hypothetical }\end{array}$ \\
\hline 70 & (R)DPYMFHQANLR(N) & 696.3342 & 1391.653 & 6.2 & AFL2G_01386 & $\begin{array}{c}\text { conserved } \\
\text { hypothetical }\end{array}$ \\
\hline 70 & (R)DQCNYSLQYTIGNK(Q) & 568.5947 & 1703.769 & 0.1 & AFL2G_01386 & $\begin{array}{l}\text { conserved } \\
\text { hypothetical }\end{array}$ \\
\hline 70 & (R)EISFNQAWLR(Q) & 632.3275 & 1263.648 & -0.3 & AFL2G_01386 & $\begin{array}{l}\text { conserved } \\
\text { hypothetical }\end{array}$ \\
\hline 70 & (K)KPLGTGTDLWPK(D) & 656.8678 & 1312.726 & 1.8 & AFL2G_01386 & $\begin{array}{l}\text { conserved } \\
\text { hypothetical }\end{array}$ \\
\hline 70 & (K)LDDLFVWWTTPANR(D) & 578.6268 & 1733.865 & 0.7 & AFL2G_01386 & $\begin{array}{l}\text { conserved } \\
\text { hypothetical }\end{array}$ \\
\hline 70 & (K)EAGLVPFQVSPTTK(F) & 737.4013 & 1473.795 & 0.4 & AFL2G_10707 & $\begin{array}{l}\text { similar to beta- } \\
\text { fructofuranosidase }\end{array}$ \\
\hline 70 & (R)FALSTWAR(Y) & 476.2575 & 951.5047 & 3.2 & AFL2G_10707 & $\begin{array}{c}\text { similar to beta- } \\
\text { fructofuranosidase }\end{array}$ \\
\hline 70 & (K)FHVLTAQLSFPR(S) & 472.5977 & 1415.779 & -0.6 & AFL2G_10707 & $\begin{array}{c}\text { similar to beta- } \\
\text { fructofuranosidase }\end{array}$ \\
\hline 70 & (K)GYPTSQQNWVGTLLLPR(E) & 644.0104 & 1930.018 & -0.8 & AFL2G_10707 & $\begin{array}{l}\text { similar to beta- } \\
\text { fructofuranosidase }\end{array}$ \\
\hline 70 & (K)LDRPPVIPLPPSDSDVTAFR(D) & 731.3966 & 2192.171 & 1.9 & AFL2G_10707 & $\begin{array}{l}\text { similar to beta- } \\
\text { fructofuranosidase }\end{array}$ \\
\hline 70 & (K)NDPVAVFDGSVIPK(G) & 729.385 & 1457.764 & -0.5 & AFL2G_10707 & $\begin{array}{l}\text { similar to beta- } \\
\text { fructofuranosidase }\end{array}$ \\
\hline 70 & (K)TISNVVDNELAR(E) & 665.8498 & 1330.696 & -2.9 & AFL2G_10707 & $\begin{array}{c}\text { similar to beta- } \\
\text { fructofuranosidase }\end{array}$ \\
\hline 70 & $(\mathrm{~K}) \operatorname{TLGIDIAR}(\mathrm{E})$ & 429.7554 & 858.5043 & -1 & AFL2G_10707 & $\begin{array}{c}\text { similar to beta- } \\
\text { fructofuranosidase }\end{array}$ \\
\hline 70 & (R)ASLGHPEPWTVK(Y) & 441.2359 & 1321.69 & 2.4 & AFL2G_03217 & $\begin{array}{c}\text { hypothetical similar } \\
\text { to alpha-L- } \\
\text { arabinoduranosidase } \\
\text { A }\end{array}$ \\
\hline
\end{tabular}




\begin{tabular}{|c|c|c|c|c|c|c|}
\hline 70 & (R)DLMQAMADFGPK(F) & 662.3087 & 1323.607 & 2.2 & AFL2G_03217 & $\begin{array}{l}\text { hypothetical similar } \\
\text { to alpha-L- } \\
\text { arabinoduranosidase } \\
\text { A }\end{array}$ \\
\hline 70 & (K)TGEVYASAVIVSK(S) & 662.3614 & 1323.716 & 0 & AFL2G_03217 & $\begin{array}{l}\text { hypothetical similar } \\
\text { to alpha-L- } \\
\text { arabinoduranosidase } \\
\text { A }\end{array}$ \\
\hline 70 & (K)YPSNLDAWIPVDGSALSLK(N) & 682.6859 & 2046.054 & -5.4 & AFL2G_03217 & $\begin{array}{l}\text { hypothetical similar } \\
\text { to alpha-L- } \\
\text { arabinoduranosidase } \\
\text { A }\end{array}$ \\
\hline 70 & (K)YVEVGNEDNLNDGLDSYK(S) & 1022.4607 & 2043.914 & 0 & AFL2G_03217 & $\begin{array}{l}\text { hypothetical similar } \\
\text { to alpha-L- } \\
\text { arabinoduranosidase } \\
\text { A }\end{array}$ \\
\hline 70 & (R)DAGNAATNDPLFPFSR(G) & 846.905 & 1692.798 & 3 & AFL2G_02099 & hypothetical protein \\
\hline 70 & (K)FATLVYAVDK(L) & 563.8144 & 1126.614 & 6.4 & AFL2G_02099 & hypothetical protein \\
\hline 70 & (K)GAVSGQTGTYSLTWGK(E) & 806.8999 & 1612.797 & -2.5 & AFL2G_02099 & hypothetical protein \\
\hline 70 & (R)GPPGWSGTVQVAK(N) & 642.3418 & 1283.674 & 1.6 & AFL2G_02099 & hypothetical protein \\
\hline 63 & (R)FYVQDGVTYPQPSADVSGLSGNTINSEYCTAENTLFEGSGSFAK(H) & 1177.7814 & 4708.131 & -5.7 & AFL2G_07571 & $\begin{array}{l}\text { exoglucanase } 1 \\
\text { precursor }\end{array}$ \\
\hline 63 & (K)LLNQEFTFDVDVSK(L) & 827.9207 & 1654.832 & 1.1 & AFL2G_07571 & $\begin{array}{l}\text { exoglucanase } 1 \\
\text { precursor }\end{array}$ \\
\hline 63 & (K)TIDTNKPITVVTQFITDDGTSSGTLSEIK(R) & 1027.8642 & 3081.584 & -1.9 & AFL2G_07571 & $\begin{array}{c}\text { exoglucanase } 1 \\
\text { precursor }\end{array}$ \\
\hline 63 & (K)TIDTNKPITVVTQFITDDGTSSGTLSEIKR(F) & 810.1758 & 3237.685 & -1.1 & AFL2G_07571 & $\begin{array}{c}\text { exoglucanase } 1 \\
\text { precursor }\end{array}$ \\
\hline 63 & (K)AYADGYVQIVQTYAASTGSMAEQYTK(T) & 939.4369 & 2816.308 & -4.3 & AFL2G_11885 & $\begin{array}{l}\text { glucoamylase } \\
\text { precursor }\end{array}$ \\
\hline 63 & (K)DINTVLGSIHTFDPQATCDDATFQPCSAR(A) & 1079.8189 & 3237.458 & -4.8 & AFL2G_11885 & $\begin{array}{c}\text { glucoamylase } \\
\text { precursor }\end{array}$ \\
\hline 63 & (R)GGDADLLPIIEEFISSQAR(I) & 1016.0153 & 2031.039 & -7.9 & AFL2G_11885 & $\begin{array}{l}\text { glucoamylase } \\
\text { precursor }\end{array}$ \\
\hline 63 & (K)IGSLAITDVSLPFFK(A) & 804.4509 & 1607.904 & -6.1 & AFL2G_11885 & $\begin{array}{c}\text { glucoamylase } \\
\text { precursor }\end{array}$ \\
\hline 60 & (K)CALDGADYSNTYGITTSGSEVR(L) & 779.6869 & 2337.03 & 6.9 & AFL2G_07571 & $\begin{array}{l}\text { exoglucanase } 1 \\
\text { precursor }\end{array}$ \\
\hline 60 & (R)FYVQDGVTYPQPSADVSGLSGNTINSEYCTAENTLFEGSGSFAK(H) & 1570.0479 & 4708.131 & -0.3 & AFL2G_07571 & $\begin{array}{l}\text { exoglucanase } 1 \\
\text { precursor }\end{array}$ \\
\hline 60 & (R)GTCSTSSGVPSEVEASNPSAYVAYSNIK(V) & 1431.6571 & 2862.31 & -1 & AFL2G_07571 & $\begin{array}{l}\text { exoglucanase } 1 \\
\text { precursor }\end{array}$ \\
\hline 60 & (K)LLNQEFTFDVDVSK(L) & 827.9161 & 1654.832 & -4.4 & AFL2G_07571 & $\begin{array}{c}\text { exoglucanase } 1 \\
\text { precursor }\end{array}$ \\
\hline 60 & (K)TIDTNKPITVVTQFITDDGTSSGTLSEIK(R) & 1027.8626 & 3081.584 & -3.4 & AFL2G_07571 & $\begin{array}{l}\text { exoglucanase } 1 \\
\text { precursor }\end{array}$ \\
\hline 60 & (K)TIDTNKPITVVTQFITDDGTSSGTLSEIKR(F) & 810.1737 & 3237.685 & -3.7 & AFL2G_07571 & $\begin{array}{l}\text { exoglucanase } 1 \\
\text { precursor }\end{array}$ \\
\hline
\end{tabular}




\begin{tabular}{|c|c|c|c|c|c|c|}
\hline 60 & (R)VYMMADDTHYEVYK(L) & 882.8812 & 1764.761 & -3.2 & AFL2G_07571 & $\begin{array}{l}\text { exoglucanase } 1 \\
\text { precursor }\end{array}$ \\
\hline 60 & (R)YSGTCDPDGCDFNPYR(V) & 962.3673 & 1923.727 & 0 & AFL2G_07571 & $\begin{array}{l}\text { exoglucanase } 1 \\
\text { precursor }\end{array}$ \\
\hline 60 & (R)EATWLSGYPTDSELYK(L) & 930.434 & 1859.87 & -4.9 & AFL2G_01841 & $\begin{array}{c}\text { alpha-amylase type- } \\
3 \text { precursor }\end{array}$ \\
\hline 60 & (R)FASYTNDIALAK(N) & 657.3367 & 1313.674 & -5.7 & AFL2G_01841 & $\begin{array}{c}\text { alpha-amylase type- } \\
3 \text { precursor }\end{array}$ \\
\hline 60 & (R)KGTDGSQIVTILSNK(G) & 520.9591 & 1560.859 & 2.3 & AFL2G_01841 & $\begin{array}{c}\text { alpha-amylase type- } \\
3 \text { precursor }\end{array}$ \\
\hline 60 & (K)NVAAFIILNDGIPIIYAGQEQHYAGGNDPANR(E) & 1137.9013 & 3411.708 & -5.5 & AFL2G_01841 & $\begin{array}{l}\text { alpha-amylase type- } \\
3 \text { precursor }\end{array}$ \\
\hline 60 & (K)NWPIYKDDTTIAMR(K) & 575.2861 & 1723.847 & -2 & AFL2G_01841 & $\begin{array}{c}\text { alpha-amylase type- } \\
3 \text { precursor }\end{array}$ \\
\hline 60 & (K)AYADGYVQIVQTYAASTGSMAEQYTK(T) & 939.4337 & 2816.308 & -7.7 & AFL2G_118865 & $\begin{array}{l}\text { glucoamylase } \\
\text { precursor }\end{array}$ \\
\hline 60 & (K)IGSLAITDVSLPFFK(A) & 804.4495 & 1607.904 & -7.8 & AFL2G_118865 & $\begin{array}{l}\text { glucoamylase } \\
\text { precursor }\end{array}$ \\
\hline 60 & (R)IQGISNPSGALSSGGLGEPK(F) & 623.6619 & 1868.971 & 0 & AFL2G_118865 & $\begin{array}{l}\text { glucoamylase } \\
\text { precursor }\end{array}$ \\
\hline 60 & $(\mathrm{~K}) \operatorname{TLVDLFR}(\mathrm{G})$ & 432.2546 & 863.4985 & 3.9 & AFL2G_118865 & $\begin{array}{c}\text { glucoamylase } \\
\text { precursor }\end{array}$ \\
\hline 60 & (R)GLATNVANYNAFSIDSCPSYTQGSTVCDEK(T) & 1090.4776 & 3269.436 & -5.5 & AFL2G_07776 & $\begin{array}{l}\text { exoglucanase } 2 \\
\text { precursor }\end{array}$ \\
\hline 60 & (K)NAAGANPPTAGIFVVYDLPDR(D) & 1079.5509 & 2158.093 & 0.8 & AFL2G_07776 & $\begin{array}{l}\text { exoglucanase } 2 \\
\text { precursor }\end{array}$ \\
\hline 60 & (K)NTGFGVRPTTDTGDELVDAFVWVKPGGESDGTSDTSAER(Y) & 1018.4718 & 4070.885 & -4.8 & AFL2G_07776 & $\begin{array}{l}\text { exoglucanase } 2 \\
\text { precursor }\end{array}$ \\
\hline 60 & (K)SAGFDAHFIVDTGR(N) & 498.2443 & 1492.718 & 0.3 & AFL2G_07776 & $\begin{array}{l}\text { exoglucanase } 2 \\
\text { precursor }\end{array}$ \\
\hline 60 & (R)GTCEPHAGDPEKVESQSGSATVTYSNIK(Y) & 738.0945 & 2949.353 & 1.1 & AFL2G_03805 & $\begin{array}{l}\text { exoglucanase } 1 \\
\text { precursor }\end{array}$ \\
\hline 60 & (K)LVDSSSPVTVVTQFITADGTDSGALSEIKR(F) & 774.1501 & 3093.595 & -5.3 & AFL2G_03805 & $\begin{array}{l}\text { exoglucanase } 1 \\
\text { precursor }\end{array}$ \\
\hline 60 & (K)VIANAASNVDGVTGNSITADFCTAQK(K) & 1312.6319 & 2624.262 & -2.1 & AFL2G_03805 & $\begin{array}{l}\text { exoglucanase } 1 \\
\text { precursor }\end{array}$ \\
\hline 58 & (R)GLATNVANYNAFSIDSCPSYTQGSTVCDEK(T) & 1090.4784 & 3269.436 & -4.7 & AFL2G_07776 & $\begin{array}{l}\text { exoglucanase } 2 \\
\text { precursor }\end{array}$ \\
\hline 58 & (K)NTGFGVRPTTDTGDELVDAFVWVKPGGESDGTSDTSAER(Y) & 1018.472 & 4070.885 & -4.6 & AFL2G_07776 & $\begin{array}{l}\text { exoglucanase } 2 \\
\text { precursor }\end{array}$ \\
\hline 58 & (K)SAGFDAHFIVDTGR(N) & 498.2455 & 1492.718 & 2.7 & AFL2G_07776 & $\begin{array}{l}\text { exoglucanase } 2 \\
\text { precursor }\end{array}$ \\
\hline 58 & (R)GTCSTSSGVPSEVEASNPSAYVAYSNIK(V) & 954.7767 & 2862.31 & 2 & AFL2G_07571 & $\begin{array}{l}\text { exoglucanase } 1 \\
\text { precursor }\end{array}$ \\
\hline 58 & (K)TIDTNKPITVVTQFITDDGTSSGTLSEIK(R) & 1027.8615 & 3081.584 & -4.5 & AFL2G_07571 & $\begin{array}{l}\text { exoglucanase } 1 \\
\text { precursor }\end{array}$ \\
\hline 58 & (K)TIDTNKPITVVTQFITDDGTSSGTLSEIKR(F) & 810.172 & 3237.685 & -5.8 & AFL2G_07571 & $\begin{array}{l}\text { exoglucanase } 1 \\
\text { precursor }\end{array}$ \\
\hline 55 & (K)FINGQANVEGWEPSDSDK(N) & 664.965 & 1992.893 & -6.5 & AFL2G_03805 & $\begin{array}{l}\text { exoglucanase } 1 \\
\text { precursor }\end{array}$ \\
\hline
\end{tabular}




\begin{tabular}{|c|c|c|c|c|c|c|}
\hline 55 & (R)FYVQGGKVIANAASNVDGVTGNSITADFCTAQKK(A) & 883.6969 & 3531.754 & 3.4 & AFL2G_03805 & $\begin{array}{l}\text { exoglucanase } 1 \\
\text { precursor }\end{array}$ \\
\hline 55 & (K)GSVVLDSNWR(W) & 566.7879 & 1132.575 & -5.3 & AFL2G_03805 & $\begin{array}{c}\text { exoglucanase } 1 \\
\text { precursor }\end{array}$ \\
\hline 55 & (R)GTCEPHAGDPEKVESQSGSATVTYSNIK(Y) & 738.0942 & 2949.353 & 0.6 & AFL2G_03805 & $\begin{array}{l}\text { exoglucanase } 1 \\
\text { precursor }\end{array}$ \\
\hline 55 & (K)LVDSSSPVTVVTQFITADGTDSGALSEIK(R) & 735.1288 & 2937.494 & 0.2 & AFL2G_03805 & $\begin{array}{l}\text { exoglucanase } 1 \\
\text { precursor }\end{array}$ \\
\hline 55 & (K)LVDSSSPVTVVTQFITADGTDSGALSEIKR(F) & 774.1561 & 3093.595 & 2.4 & AFL2G_03805 & $\begin{array}{l}\text { exoglucanase } 1 \\
\text { precursor }\end{array}$ \\
\hline 55 & (K)VESQSGSATVTYSNIK(Y) & 557.6132 & 1670.823 & 1.1 & AFL2G_03805 & $\begin{array}{l}\text { exoglucanase } 1 \\
\text { precursor }\end{array}$ \\
\hline 55 & (K)VIANAASNVDGVTGNSITADFCTAQK(K) & 1312.6356 & 2624.262 & 0.7 & AFL2G_03805 & $\begin{array}{c}\text { exoglucanase } 1 \\
\text { precursor }\end{array}$ \\
\hline 55 & (K)VIANAASNVDGVTGNSITADFCTAQKK(A) & 918.1229 & 2752.357 & -1 & AFL2G_03805 & $\begin{array}{c}\text { exoglucanase } 1 \\
\text { precursor }\end{array}$ \\
\hline 55 & (R)YAGTCDPDGCDFNAYR(M) & 627.9104 & 1881.717 & 0 & AFL2G_03805 & $\begin{array}{c}\text { exoglucanase } 1 \\
\text { precursor }\end{array}$ \\
\hline 55 & (K)YGTGYCDSQCPR(D) & 732.2868 & 1463.568 & -1 & AFL2G_03805 & $\begin{array}{l}\text { exoglucanase } 1 \\
\text { precursor }\end{array}$ \\
\hline 55 & (K)ALVEGDAFAK(A) & 510.7737 & 1020.536 & 4 & AFL2G_02658 & $\begin{array}{c}\text { glucoamylase } 1 \\
\text { precurosr }\end{array}$ \\
\hline 55 & (R)ASALIAYGNSLISSDK(Q) & 805.4238 & 1609.843 & -1.8 & AFL2G_02658 & $\begin{array}{c}\text { glucoamylase } 1 \\
\text { precurosr }\end{array}$ \\
\hline 55 & (K)QGVLNNIGADGK(L) & 593.3128 & 1185.622 & -3.3 & AFL2G_02658 & $\begin{array}{c}\text { glucoamylase } 1 \\
\text { precurosr }\end{array}$ \\
\hline 55 & (K)QQAVSNPSGSLSDGSGLAEPK(F) & 1014.9868 & 2028.983 & -8.3 & AFL2G_02658 & $\begin{array}{c}\text { glucoamylase } 1 \\
\text { precurosr }\end{array}$ \\
\hline 55 & (R)SGLDTNSLLGSIHTFDPAAACDDTTFQPCSSR(A) & 1147.8471 & 3441.532 & -1.6 & AFL2G_02658 & $\begin{array}{l}\text { glucoamylase } 1 \\
\text { precurosr }\end{array}$ \\
\hline 55 & (K)SNPDYFYTWTR(D) & 725.32 & 1449.643 & -7.3 & AFL2G_02658 & $\begin{array}{c}\text { glucoamylase } 1 \\
\text { precurosr }\end{array}$ \\
\hline 55 & (K)SSSAYESLTSAVK(T) & 665.3276 & 1329.653 & -4 & AFL2G_02658 & $\begin{array}{c}\text { glucoamylase } 1 \\
\text { precurosr }\end{array}$ \\
\hline 55 & (K)TYADGFISVVQEYTPDGGALAEQYSR(D) & 946.4438 & 2837.326 & -3.4 & AFL2G_02658 & $\begin{array}{c}\text { glucoamylase } 1 \\
\text { precurosr }\end{array}$ \\
\hline 55 & (K)FTATSAQTGAATLR(I) & 698.365 & 1395.723 & 0 & AFL2G_05136 & $\begin{array}{c}\text { hypothetical similar } \\
\text { to } \\
\text { rhamnogalacturonan } \\
\text { lyase } \mathrm{A}\end{array}$ \\
\hline 55 & (R)GTVSGTASGADSSFK(W) & 686.3239 & 1371.639 & 1.4 & AFL2G_05136 & $\begin{array}{c}\text { hypothetical similar } \\
\text { to } \\
\text { rhamnogalacturonan } \\
\text { lyase } \mathrm{A}\end{array}$ \\
\hline 55 & (K)GVNDPVTIK(F) & 471.7672 & 942.5255 & 1.8 & AFL2G_05136 & $\begin{array}{c}\text { hypothetical similar } \\
\text { to } \\
\text { rhamnogalacturonan } \\
\text { lyase A } \\
\end{array}$ \\
\hline 55 & (R)IGTTLSFAGGRPQATINDYEGSAPSAPTNLNSR(G) & 1121.8865 & 3363.656 & -3.4 & AFL2G_05136 & $\begin{array}{c}\text { hypothetical similar } \\
\text { to } \\
\text { rhamnogalacturonan } \\
\text { lyase A }\end{array}$ \\
\hline 55 & (K)VAETSVSVTAGSSTSK(D) & 755.8858 & 1510.76 & 3.2 & AFL2G_05136 & $\begin{array}{c}\text { hypothetical similar } \\
\text { to } \\
\text { rhamnogalacturonan } \\
\text { lyase } \mathrm{A}\end{array}$ \\
\hline
\end{tabular}




\begin{tabular}{|c|c|c|c|c|c|c|}
\hline 55 & (R)VCMILNQYETSSGGPFFR(D) & 702.6627 & 2105.978 & -2.3 & AFL2G_05136 & $\begin{array}{c}\text { hypothetical similar } \\
\text { to } \\
\text { rhamnogalacturonan } \\
\text { lyase A }\end{array}$ \\
\hline 55 & (K)DLPQVISTSYGENEQEIPEK(Y) & 759.3675 & 2276.093 & -2.2 & AFL2G_05009 & $\begin{array}{l}\text { hypothetical similar } \\
\text { to tripeptidyl } \\
\text { aminopeptidase }\end{array}$ \\
\hline 55 & (K)ELYNIGDYQADANSGSK(I) & 922.919 & 1844.83 & 0.5 & AFL2G_05009 & $\begin{array}{l}\text { hypothetical similar } \\
\text { to tripeptidyl } \\
\text { aminopeptidase }\end{array}$ \\
\hline 55 & (K)IAFASYLEEYAR(Y) & 716.8593 & 1432.711 & 0.4 & AFL2G_05009 & $\begin{array}{l}\text { hypothetical similar } \\
\text { to tripeptidyl } \\
\text { aminopeptidase }\end{array}$ \\
\hline 55 & (R)TVCNLIAQLGSR(G) & 666.3575 & 1331.71 & -1.7 & AFL2G_05009 & $\begin{array}{l}\text { hypothetical similar } \\
\text { to tripeptidyl } \\
\text { aminopeptidase }\end{array}$ \\
\hline 55 & (R)YADLENFENYLAPWAK(G) & 972.4653 & 1943.917 & 3 & AFL2G_05009 & $\begin{array}{l}\text { hypothetical similar } \\
\text { to tripeptidyl } \\
\text { aminopeptidase }\end{array}$ \\
\hline 55 & (R)EATWLSGYPTDSELYK(L) & 930.4392 & 1859.87 & 0.7 & AFL2G_01841 & $\begin{array}{c}\text { alpha-amylase type- } \\
3 \text { precursor }\end{array}$ \\
\hline 55 & (R)FASYTNDIALAK(N) & 657.3363 & 1313.674 & -6.3 & AFL2G_01841 & $\begin{array}{c}\text { alpha-amylase type- } \\
3 \text { precursor }\end{array}$ \\
\hline 55 & (R)SQSIYFLLTDR(F) & 671.8531 & 1342.7 & -0.9 & AFL2G_01841 & $\begin{array}{c}\text { alpha-amylase type- } \\
3 \text { precursor }\end{array}$ \\
\hline 41 & (R)GTCSTSSGVPSEVEASNPSAYVAYSNIK(V) & 954.7746 & 2862.31 & -0.2 & AFL2G_07571 & $\begin{array}{l}\text { exoglucanase } 1 \\
\text { precursor }\end{array}$ \\
\hline 41 & (K)TIDTNKPITVVTQFITDDGTSSGTLSEIK(R) & 1027.8632 & 3081.584 & -2.8 & AFL2G_07571 & $\begin{array}{l}\text { exoglucanase } 1 \\
\text { precursor }\end{array}$ \\
\hline 41 & (K)TIDTNKPITVVTQFITDDGTSSGTLSEIKR(F) & 810.1735 & 3237.685 & -3.9 & AFL2G_07571 & $\begin{array}{l}\text { exoglucanase } 1 \\
\text { precursor }\end{array}$ \\
\hline 40 & (K)GVTGGGSAAAVYPTTTDELVSYLGDSSPR(V) & 943.455 & 2828.359 & -2.8 & AFL2G-11352 & $\begin{array}{l}\text { pectin lyase A } \\
\text { precursor }\end{array}$ \\
\hline 40 & (R)IVSGASNIIIQNIAITDLNPK(Y) & 1097.6236 & 2194.244 & -1.9 & AFL2G-11352 & $\begin{array}{l}\text { pectin lyase } A \\
\text { precursor }\end{array}$ \\
\hline 40 & (K)NIASASPYADAQSSVPSSAGQGNL(-) & 1146.5391 & 2292.074 & -1.3 & AFL2G-11352 & $\begin{array}{c}\text { pectin lyase } A \\
\text { precursor }\end{array}$ \\
\hline 27 & (K)DAYNAIIDAL(-) & 539.7728 & 1078.542 & -3 & AFL2G_11983 & $\begin{array}{l}\text { hypothetical similar } \\
\text { to xylanase F1 }\end{array}$ \\
\hline 27 & (R)DSVFSQVLGEDFVR(I) & 799.3978 & 1597.786 & 1.7 & AFL2G_11983 & $\begin{array}{l}\text { hypothetical similar } \\
\text { to xylanase F1 }\end{array}$ \\
\hline 27 & (K)KYFGTCSDQALLQNSQNEAIVR(A) & 848.0819 & 2542.236 & -1.7 & AFL2G_11983 & $\begin{array}{l}\text { hypothetical similar } \\
\text { to xylanase } \mathrm{F} 1\end{array}$ \\
\hline 27 & (K)LYINDYNLDSADYAK(T) & 889.4188 & 1777.828 & 1.4 & AFL2G_11983 & $\begin{array}{l}\text { hypothetical similar } \\
\text { to xylanase F1 }\end{array}$ \\
\hline 27 & (R)SSTSPLLFDSNYQAK(D) & 829.4074 & 1657.807 & 0.4 & AFL2G_11983 & $\begin{array}{l}\text { hypothetical similar } \\
\text { to xylanase } \mathrm{F} 1\end{array}$ \\
\hline 27 & (K)YFGTCSDQALLQNSQNEAIVR(A) & 805.3847 & 2414.141 & -0.4 & AFL2G_11983 & $\begin{array}{l}\text { hypothetical similar } \\
\text { to xylanase } \mathrm{F} 1\end{array}$ \\
\hline 27 & (R)YKGQIYAWDVVNEIFDEDGTLR(D) & 877.7587 & 2631.273 & -4.2 & AFL2G_11983 & $\begin{array}{l}\text { hypothetical similar } \\
\text { to xylanase F1 }\end{array}$ \\
\hline
\end{tabular}

243 There were several peptide matches to proteins from the 55-kD band region including an

244 exoglucanase 1 precursor (AFL2G_03805), a glucoamylase 1 precursor (AFL2G_02658), a

245 hypothetical protein similar to rhamnogalacturonan lyase A (AFL2G_05136), a hypothetical 
246 protein similar to tripeptidyl aminopeptidase (AFL2G_05009), and an $\alpha$-amylase A type 3

247 precursor (AFL2G_01841) (Tables 1 and 2). The protein identified from the 41-kD band region

248 was an exoglucanase 1 precursor (AFL2G_07571). The 40-kD band region provided

249 identification of a pectin lyase A precursor (AFL2G_11352) (Table s 1 and 2). Results from the

250 27-kD band region identified a hypothetical protein similar to xylanase F1 (AFL2G_11983). No

251 protein identifications were obtained from the $20-\mathrm{kD}$ and $25-\mathrm{kD}$ gel bands.

\section{Discussion}

253 Cotton carpellary tissue provides a valuable defensive function (physical/mechanical barrier)

254 for the host plant, namely the ability to resist penetration of potential pathogens between locules

255 of the cotton boll. Cotton seed contains significant concentrations of lipids (triglycerides),

256 storage proteins and raffinose that are potential fungal nutrients. In addition, A. flavus is a

257 known opportunistic pathogen of cottonseed. Thus, cotton carpel tissue is a prime target tissue

258 for fungal penetration in order to attain nutrient capture.

259 A. flavus secreted at least two separate endoxylanase activities when exposed to cotton carpel

260 tissue as a sole carbon source. They vary considerably in molecular weight (14 kD vs. $27 \mathrm{kD}$,

261 respectively). The smaller molecular weight xylanase (Fig. 1) appeared to display a comparable

262 xylanase activity with respect to the $27 \mathrm{kD}$ protein in the utilized plate assay. A $14 \mathrm{kD}$

263 endoxylanase secreted by A. flavus has been characterized as a heat stable endo-1,4- $\beta$-D-

264 xylanase [21]. While both proteins are active in the xylanase assay used in this study (cleavage

265 of oat spelt RBB-xylan), they may possess substantially different native substrate specificities.

266 The identification of multiple glucanase proteins (endo and exo) suggests these hydrolytic

267 activities are important for digestion of cellulose and xyloglucan moieties (primary cell wall).

268 The presence of both $\beta$ and $\alpha$ furanosidase proteins indicates fungal hydrolysis of arabinose/ 
269 fructan moieties in the carpel substrate. Previous work has shown the presence of

270 arabinogalactan proteins in the secondary wall structure of cotton carpel tissue [22]. Although

271 identification of an arabinogalactan endo-1,4- $\beta$-galactosidase in a 40-kD band was not strongly

272 supported by our mass spectrometry data (we observed only 2 peptide matches), its presence

273 would be consistent with degradation of this protein class. Fungal glucoamylase proteins are

274 presumably secreted to assist in digestion of cellulose fibrils (primary wall). Alpha-amylase

275 proteins may assist with digestion of $\alpha$-linked glucose moieties. The presence of pectate lyase A

276 proteins suggests that this class of pectolytic enzyme is more important for breaching carpel

277 tissue than is A. flavus pectinase P2c which was not identified in this study. Identification of

278 xylanase F1 is presumed to be the source of the secondary xylanase activity obtained from fungal

279 medium samples. There were only 2 peptide matches to a fungal acetylxylan esterase, but this is

280 consistent with the presence of acetyl moieties on the xylans, requiring removal to allow

281 xylanase access to its substrate. The presence of glutaminase A with the fungal-secreted proteins

282 suggests the involvement of a nitrogen regulation facet to this fungal polysaccharide degradation

283 process. This protein has also been observed in protein samples derived from A. flavus cultures

284 grown on a xylan medium (data not shown; manuscript in preparation). In addition to the

285 identified fungal proteins, a number of conserved hypothetical proteins with no known function

286 were identified.

287 There are several examples in the obtained data set where the same protein was identified in 288 different molecular weight gel bands (e.g. AFL2G_07571, exoglucanase 1 precursor). In the 289 case where identified protein molecular weights differ by 2 to $3 \mathrm{kD}$, the presence of a signal 290 peptide with resultant cleavage could explain this result. In the case where the observed protein 291 molecular weights vary by up to $20 \mathrm{kD}$, other explanations must be tendered. Since these $A$. 
292 flavus-secreted proteins were subjected to considerable concentration procedures before

293 application to gel filtration chromatography, it is possible that some protein degradation occurred

294 from indigenous fungal proteases contained in the medium sample. It should be noted that a

295 protein similar to tripeptidyl aminopeptidase (AFL2G_05009) was identified in the secreted

296 protein sample, lending support to this hypothesis. In addition, since these fungal cultures were

297 incubated for 6 days, substantial protein degradation/decomposition could occur during this

298 period. It is also possible that identified precursor proteins were subsequently processed to their

299 mature active molecular sizes.

300 The protein profile observed from A. flavus culture medium containing cotton carpel tissue

301 was similar to the protein profile obtained from A. flavus cultures grown on the larch xylan

302 medium. With both media, the fungus secreted two distinct endoxylanases that appear to be very

303 similar in each case. In the xylan medium, A. flavus secretion of a minor and major esterase

304 activity was observed. The major esterase activity secreted in the larch xylan fermentation was

305 identified as an acetylxylan esterase (data not shown). The only major difference between these

306 medium profiles appears to be the prolific production of a pectolytic activity in the carpel

307 medium. Since the protein profile produced in the carpel medium appears to be more complex

308 than that observed in the xylan medium, there are undoubtedly additional accessory hydrolases

309 present in the carpel medium.

310 Cotton carpel tissue (35-45 days post-anthesis) that had been treated with a mixture of

311 xylanolytic hydrolases derived from A. flavus was subjected to immunocytochemical analysis.

312 Untreated control tissue cells revealed the presence of high concentrations of

313 xylans/arabinoxylans throughout the cell wall [22]. Microscopic examination of hydrolase-

314 treated tissues revealed severe degradation of the secondary wall structure [22]. Hydrolase 
315 treatment essentially removed the xylans/arabinoxylans from the carpel walls, leaving the pectin

316 moieties intact. Pectinase plate assays confirmed the absence of pectolytic activity in the crude

317 A. flavus xylanolytic hydrolase preparation. A study in which 20 to 25 dpa cotton bolls were

318 inoculated with several different atoxigenic $A$. flavus strains identified exoglucanase 1 and

319 rhamnogalacturonan lyase A proteins present in the fungal-cotton carpel in vivo interaction [23].

320 This data supports the importance of these classes of fungal hydrolases needed for breaching

321 cotton defensive barriers.

322 Analysis of the $14 \mathrm{kD}$ protein secreted in the xylanolytic hydrolase mixture by trypsin

323 digestion/tandem mass spectrometry revealed peptide fragments from a single xylanase $(x \ln A$;

324 AO090120000026) of the five xylanases annotated in the A. flavus genome [21]. Examination

325 of the genomic sequence of $x \ln A$ revealed the presence of consensus binding sites for the

326 regulatory proteins $\mathrm{X} \operatorname{lnR}, \mathrm{CreA}$, and PacC. In A. niger, XlnR induces the production of

327 endoxylanases and $\beta$-xylosidase, along with a number of accessory enzymes important for

328 hemicellulose digestion [24]. A homolog to the A. niger XlnR is seen in A. oryzae. This raises

329 the strong possibility that xylanases are regulated in a similar manner in the two Aspergilli. In

330 addition, A. flavus is closely related to A. orzae (they may be ecotypes; see discussion in [3]),

331 again suggesting similar regulatory processes are present for secretion of xylanolytic hydrolases

332 in these fungi.

333 In Aspergillus, CreA is responsible for carbon catabolite repression, in which target enzymes

334 are not expressed in the presence of easily metabolized carbon sources (e.g. glucose, fructose,

335 etc.). Endoxylanases and $\beta$-xylosidases have been shown to be repressed by CreA in A. nidulans

$336[25,26]$. When control cultures of A. flavus were grown on a medium containing glucose as a 
337 sole carbon source, no xylanase activity was detected, suggesting that this class of enzymes is

338 subject to carbon catabolite repression.

339 PacC is the global $\mathrm{pH}$ regulator in A. nidulans. It promotes transcription of alkaline-

340 expressed genes $(\mathrm{pH}>7)$ and represses transcription of acid-expressed genes [27]. There is a

341 PacC binding site upstream of the gene encoding the major endoxylanase $(x y n F)$ of $A$. oryzae,

342 suggesting a role for $\mathrm{pH}$ regulation in xylanolytic enzymes.

343 Growth of $A$. flavus on a medium containing cotton carpel tissue resulted in fungal secretion

344 of a mixture of xylanolytic hydrolases similar to that observed when A. flavus was grown on a

345 xylan medium, except that a pectolytic activity was also produced. Many of the A. flavus-

346 produced hydrolases appear to function in the removal of xylan substituents, allowing full access

347 of the endoxylanases to the xylan backbone substrate. These results are consistent with the

348 conclusion that the xylanolytic hydrolase complex of A. flavus is an important factor in host cell

349 wall maceration. Of note is the secretion of both xylanolytic and pectolytic hydrolases when the

350 fungus was exposed to an in vivo cotton defensive tissue, suggesting that both xylanolytic

351 hydrolases and pectolytic hydrolases are important fungal virulence factors in plant hosts. Both

352 classes of hydrolases, as well as glucanases, appear to be required for complete maceration of

353 host defensive barriers that retard fungal access to oilseed reserve materials. Future work

354 characterizing A. flavus strains lacking the genes encoding these enzymes may allow us to

355 establish their roles as virulence factors in host tissue invasion.

357 Acknowledgment - The technical assistance of D. Downey is greatly appreciated. Cotton bolls 358 were provided by the generous assistance of D. Hinchliffe. Mention of trade names or 359 commercial products in this article is solely for the purpose of providing specific information and 360 does not imply recommendation or endorsement by the USDA. 
362

363

364

365

366

367

368

369

370

371

372

373

374

375

376

377

378

379

380

381

382

383

\section{References}

[1] M.A. Klich. Biogeography of Aspergillus species in soil and litter. Mycologia 94 (2002) 21-27.

[2] J.L. Richard, G.A. Payne, A.E. Desjardins, C. Maragos, W.P. Norred, J.J. Pestka, T.D. Phillips, H.P. van Egmond, P.J. Vardon, T.B. Whitaker, G.Wood. Mycotoxins: risks in plant, animal and human systems. Council for agricultural science and technology task force, 2003 (139), $i-x v i, 1-199$.

[3] J.E. Mellon, P.J. Cotty, M.K. Dowd. Aspergillus flavus hydrolases: their roles in pathogenesis and substrate utilization. Appl. Microbiol. Biotechnol. 77 (2007) 497-504.

[4] N. Carpita, M. McCann. The cell wall. In: Buchanan B, Gruissem W, Jones R, editors. Biochemistry \& Molecular Biology of Plants, Rockville, Maryland, USA: American Society of Plant Physiologists; 2000, p. 52-108.

[5] J. Chen, W. Liu, C.-M. Liu, T. Li, R.-H. Liang, S.-J. Luo. Pectin modifications: a review. Crit. Rev. Food Sci. Nut. 55 (2015) 1684-1698.

[6] V. Lionetti, F. Cervone, G. DeLorenzo. A lower content of de-methylesterfied homogalacturonan improves enzymatic cell separation and isolation of mesophyll protoplasts in Arabidopsis. Phytochemistry 112 (2015) 188-194.

[7] A. Collmer, N.T. Keen. The role of pectic enzymes in plant pathogenesis. Ann. Rev. Phytopathol. 24 (1986) 383-409.

[8] T.E. Cleveland, P.J. Cotty. Invasiveness of Aspergillus flavus isolates in wounded cotton bolls is associated with production of a specific fungal polygalacturonase. Phytopathology 81 (1991) 155-158. 
384 [9] M.P. Whitehead, M.T. Sheih, T.E. Cleveland, J.W. Cary, R.A. Dean. Isolation and

385 characterization of polygalacturonase genes (pecA and pecB) from Aspergillus flavus. Appl.

386 Environ. Microbiol. 61 (1995) 3316-3322.

387 [10] M.T. Sheih, R.L. Brown, M.P. Whitehead, J.W. Cary, P.J. Cotty, T.E. Cleveland, R.A.

388 Dean. Molecular genetic evidence for the involvement of a specific polygalacturonase, P2c,

389 in the invasion and spread of Aspergillus flavus in cotton bolls. Appl. Environ. Microbiol. 63

$390 \quad$ (1997) 3548-3552.

391 [11] D.J. Cosgrove. Relaxation in a high-stress environment: the molecular bases of extensible

392 cell walls and cell enlargement. Plant Cell 9 (1997) 1031-1041.

393 [12] R.P. deVries, J. Visser. Aspergillus enzymes involved in degradation of plant cell wall

394 polysaccharides. Microbiol. Mol. Biol. Rev. 65 (2001) 497-522.

395 [13] P.J. Cotty. Virulence and cultural characteristics of two Aspergillus flavus strains

396 pathogenic on cotton. Phytopathology 79 (1989) 808-814.

397 [14] W.R. Meredith. Registration of MD52ne high fiber quality cotton germplasm and re-

$398 \quad$ current parent MD90ne. Crop Sci. 45 (2005) 1114-1119.

399 [15] J. Adye, R.I. Mateles. Incorporation of labeled compounds into aflatoxins. Biochim.

$400 \quad$ Biophys. Acta 86 (1964) 418-420.

401 [16] P.J. Cotty. Aflatoxin and sclerotial production by Aspergillus flavus: influence of $\mathrm{pH}$.

$402 \quad$ Phytopathology 78 (1988) 1250-1253.

403 [17] P. Biely, D. Mislovicova, R. Toman. Soluble chromogenic substrates for the assay

404 of endo-1,4- $\beta$-xylanases and endo-1,4- $\beta$-glucanases. Anal. Biochem. 144 (1985) 142-46.

405 [18] J.E. Mellon. Extracellular xylanolytic and pectinolytic hydrolase production by Aspergillus

406 flavus isolates contributes to crop invasion. Toxins 7 (2015) 3257-3266. 
407 [19] U.K. Laemmli. Cleavage of structural proteins during the assembly of the head of

408 bacteriophage T4. Nature 227 (1970) 680-685.

409 [20] J.E. Mellon, P.J. Cotty. Preliminary purification and characterization of a xylanase activity

410 from Aspergillus flavus. Proceedings, Beltwide Cotton Conferences. 2007, p 147-152.

411 [21] J.E. Mellon, P.J. Cotty, K.A. Callicott, H. Abbas. Identification of a major xylanase from

412 Aspergillus flavus as a 14-kD protein. Mycopathologia 172 (2011) 299-305.

413 (DOI:10.1007/s11046-011-9425-7).

414 [22] J.E. Mellon, K.C. Vaughn. Immunohistochemical investigation of cotton carpel tissue 415 exposed to xylanolytic hydrolases of Aspergillus flavus. Physiol. Mol. Plant Pathol. 76 $416 \quad$ (2011) 34-38.

417 [23] J.E. Mellon, C.P. Mattison, C.C. Grimm. Aspergillus flavus-secreted proteins during an in 418 vivo fungal-cotton carpel tissue interaction. Physiol. Mol. Plant Pathol. 92 (2015) 38-41.

419 [24] N.N.M.E. van Peij, M.M.C. Gielkens, R.P. de Vries, J. Visser, L.H. de Graaff. The transcriptional 420 activator XlnR regulates both xylanolytic and endoglucanase gene expression in Aspergillus niger. 421 Appl. Environ. Microbiol. 64 (1998) 3615-3619.

422 [25] S. Kumar, D. Ramón. Purification and regulation of the synthesis of a $\beta$-xylosidase 423 from Aspergillus nidulans. FEMS Microbiol. Lett. 135 (1996) 287-293.

424 [26] F. Piñaga, M.T. Fernández-Espinar, S. Vallés, D. Ramón. Xylanase production in 425 Aspergillus nidulans: induction and carbon catabolite repression. FEMS Microbiol. Lett.

$426 \quad 115$ (1994) 319-324.

427 [27] J. Tilburn, S. Sarkar, D.A. Widdick, E.A. Espeso, M. Orejas, J. Mungroo, M.A. Peñalva, H.N. Arst

428 Jr. The Aspergillus PacC zinc finger transcription factor mediates regulation of both acid- and 429 alkaline-expressed genes by ambient pH. EMBO J. 14 (1995) 779-790. 